International Journal of Social Science (IJSS)

Vol.1 Issue.4 December 2021, pp: 437-448

ISSN: 2798-3463 (Printed) | 2798-4079 (Online)

\title{
IMPLEMENTING A CANVAS BUSINESS MODEL IN DWH BILEBANTE AND DWH SESAOT'S TOURISM PACKAGE INNOVATION
}

\author{
By \\ Endang Sri Wahyuni ${ }^{1}$, Supardi ${ }^{2}$, IAY Sari Dewi Utami Pidada ${ }^{3}$ \\ ${ }_{1,2,3}$ Politeknik Pariwisata Lombok \\ Email: ${ }^{1}$ endang.wahyuni@ppl.ac.id, ${ }^{2}$ supardi@ppl.ac.id, ${ }^{3}$ dayu.utami@ppl.ac.id
}

\begin{abstract}
Article Info
Article History:

Received:16-10-21

Revised : 18-11-21

Accepted: 27-11-2021

Keywords:

$\mathrm{BMC}$,

Innovation,

Tour Packages

ABSTRACT

Bilebante Green Tourism Village Central Lombok and Sesaot Green Tourism Village are two tourist villages that have the same history in building and developing tourist villages. DWH Bilebante was first initiated for its development by the Putri Renjani cooperative. At the same time, DWH Sesaot was ideated and set for the first time by the Sugeh Engger Sesaot Cooperative. The cooperative has a business unit, DWH, which is tasked with developing tourism businesses to increase cooperative profits. The two DWHs were also facilitated in 2014 by GIZ (Gesellschaft fur Internationale Zusammenarbeit), an institution from Germany whose primary focus is building the Government of Indonesia to develop Tourism Villages. These two villages were significantly impacted by the organization's assistance in developing the village into tourist spots.This study aims to find out how the tour packagesinnovationoccurred at DWH Bilebante and DWH Sesaot. This research describes how to tour package innovations and product designs are carried out using a business model BMC (business model canvas). This research is qualitative. The reference for innovation comes from Law No. 19. Innovation is a research, development, and/or engineering activity carried out to develop the practical application of new scientific values and contexts or new ways to apply existing science and technology into products or production processes.This research was included in the research and development study, and the engineering carried out for the development.So, this study views the process in Research \& Development developed by Sugiono (2008:40). It can be used to describe how the tour package innovations were carried out by the two DWHs, Bilebante and Sesaot. The stage starts from finding potential and problems, data collection, product design, design validation, redesign vision, product testing, product revision, product testing, potential and problems, mass production (marketing). The study results are DWH Bilebante, and DWH Sesaot have carried out various tour package innovations but have not implemented BMC (business model canvas) to innovate tour package products.They have stepped up the process without going through product designs made in BMC, so the resulting product has no desirability, feasibility, viability. Thus these two DWHs have not been able to sell tour packages optimally with maximum value.
\end{abstract}

This is an open access article under the CC BY-SA license.

Corresponding Author:

Endang Sri Wahyuni

Politeknik Pariwisata Lombok,

Email: endang.wahyuni@ppl.ac.id

\section{INTRODUCTION}

Bilebante Green and Sesaot GreenTourism Village, Central Lombok Tourism Village, are two tourist villages with the same history in building and developing tourist villages. The Putri Renjani cooperative was firstly initiated to develop DWH Bilebante, whileDWH Sesaot was promoted and designed for the first time by the Sugeh Engger Sesaot Cooperative. In the cooperative, there is a business unit, DWH, with the main task of developing tourism businesses to increase thecooperative profits. 
In 2014, these two Tourism Villages were helped by GIZ (Gesellschaft fur Internationale Zusammenarbeit), which is an organization from Germany whose primary focus is to help the Indonesian government to develop Tourism Villages.The impact of the organization's assistance was incredibly significant in developing the village into a tourism village. The service built by GIZ is to improve the capacity of qualified human resources with professional skills to support the development and expand the town into a green tourism village.In addition to providing reliable skills, GIZ also connects tourism villages with various government and non-government institutions toactively developtourism villages. The government agenciesincluded the Ministry of Cooperatives, the Ministry of Tourism, Bappenas, the Ministry of Villages, BUMN, and related agencies. Meanwhile, the non-government organization was Martha Tilaar.

At this time,GIZ's success in helping the tourism villages'development was seen, especially in DWH Bilebante. At the same time, the fitness center market facilities are expected to be used in early 2022. Additionally, DWH Bilebante has been visited by two different Ministers of Tourism, that is,in 2018 by the minister of tourism Arief Yahya and in early 2020, the minister of tourism and creative economy Sandiaga Uno.The GIZ assisted the two DWHs in making tour packages used as attractions to bring tourists to visit DWH.The tour packages established were included bicycle packages, homestay packages, fishing market packages, and tracking packages.

Tour packages are part of service products produced by the travel industry that can be sold by a travel company or a transportation company collaborating with a travel company.In other words, this tour package is a tourism product that is a traveling component arranged and sold to provide easiness and certainty in the traveling tour.

Many studies have been conducted related to tour packages (it can be included as an innovative), such as Fransiska et al. 2020, Widya's research 2019, Hafizh 2018, on what product should be made. The other research topic on innovation in tourism has not been well-studied (Hall \& Williams, 2019; Mansharamani, 2005); it remains an underdeveloped research area, with the consensus of common opinion was relatively rare.However, it does not seem to rule out service-based innovation as a potential element that maintains tourist patronage by developing a positive destination image (Akroush, Jraisat, Kurdieh, AL-Faouri, \& Qatu, 2016). That was Cheng's approach,Nikhashemi, and Dent (2020) further recognize service innovation, which is an aspect of the product, process, organization, and marketing, as a significant predictor in flourishing tourist satisfaction and retention. While Ristawati, Saufi, and Rinuastuti's (2019) research reveal the destination's image as an intermediary construct resulting in satisfaction of both innovation's value and experience.

The rectifying and innovation process in the service companies is a continuous process. To improve this process,the managers must know what to do, how to do it, and the appropriate method.Practical methods and techniques are more suitable to improve service delivery systems (quality of delivery): continuously collect and analyze flight departure delays and waiting times on the phone, investigate complaints, shopping mysteries, etcetera.Further other innovation methods are brainstorming, brainwriting, lateral thinking, mapping thoughts (W. Faché, 2000).

A robust method for both strategies is customer surveys (loyal, repeat, first-time, and lost customers). This is an excellent starting point for developing a quality management strategy, as it attracts everyone's attention involved in the customer.Client orientation is fundamental in improving and innovating services. What's more, the survey results confront all employees in a company with a fact they didnot know before, the difference between the service expectations expressed by customers and the expected expectations. Customer surveys can be a powerful source of information for improvement and innovation. (W. Fache, 2000).

The studies mentioned above may be resulting inthe service innovations and methods to innovate. However, the research conducted in the Green Bilebante Tourism Village and Sesaot Green Tourism Village, which are pretty well-knownTourism Villages and continue to build attractions, will focus on the innovation process corresponding to the definition of Law No. 19 of 2002. Innovation is a research, development, and engineering activity carried out for developing the practical applications of new scientific values and contexts or the new ways to apply the existing science and technology into products or production processes. Then, this research involves the stages in research, development, and or engineering that are carried out to develop practical applications of new scientific values and contexts or the new ways to apply the existing science and technology into products or production processes.So this study views the process in Research \& Development developed by Sugiono (2008:40) can be used to describe how the tour package innovations carried out by the two DWHs in which the process will also be analyzed using BMC (Canvas Business Model).The problem formulation in this research is: how is the tour packagesinnovation in Bilebante Green Tourism Village and Sesaot Green Tourism Village. The study's objective is to: Know how to innovate tour packages in Bilebante Green Tourism Village and Sesaot Green Tourism Village. 
International Journal of Social Science (IJSS)

Vol.1 Issue.4 December 2021, pp: 437-448

ISSN: 2798-3463 (Printed) | 2798-4079 (Online)

DOI: https://doi.org/10.53625/ijss.v1i4.735

\section{THEORETICAL FRAMEWORK}

\section{Definition of Innovation}

Innovation. According to Hills\& Gerald (2008), innovation is an idea, practice, or object considered new by an individual or other user unit. Suryana (2003:10) defines innovation: "as the ability to implement creativity to solve problems and opportunities to improve and enrich life."A company can use the new organizational forms and processes to increase its ability to seek new opportunities internally, such as technological advances, and externally, such as new markets or expanding markets. This is what makes entrepreneurial success.Georgellis, Joyce, and Woods (2001) state that an entrepreneurial business is described by its capacity to plan, innovate, and willingness to take risks, will ease to make innovation, and develop and grow successfully.

Innovation according to the Law No.19 of 2002, the definition of innovation is a research, development, and or engineering activity carried out for developing the practical application of new scientific values and contexts or new ways to implement the existing science and technology into products or production processes.Referring to the law on the definition of innovation, Law No. 19 of 2002, the innovation is a research, development, and or engineering activity carried out for developing the practical application of new scientific values and contexts, or new ways to implement to the existing science and technology into products or production processes. So, this study views the stages in Research \& Development developed by Sugiono (2008:40) to describe how the tour package innovations were carried out by the two DWHs, Bilebante and Sesaot. Those processes are as follows:

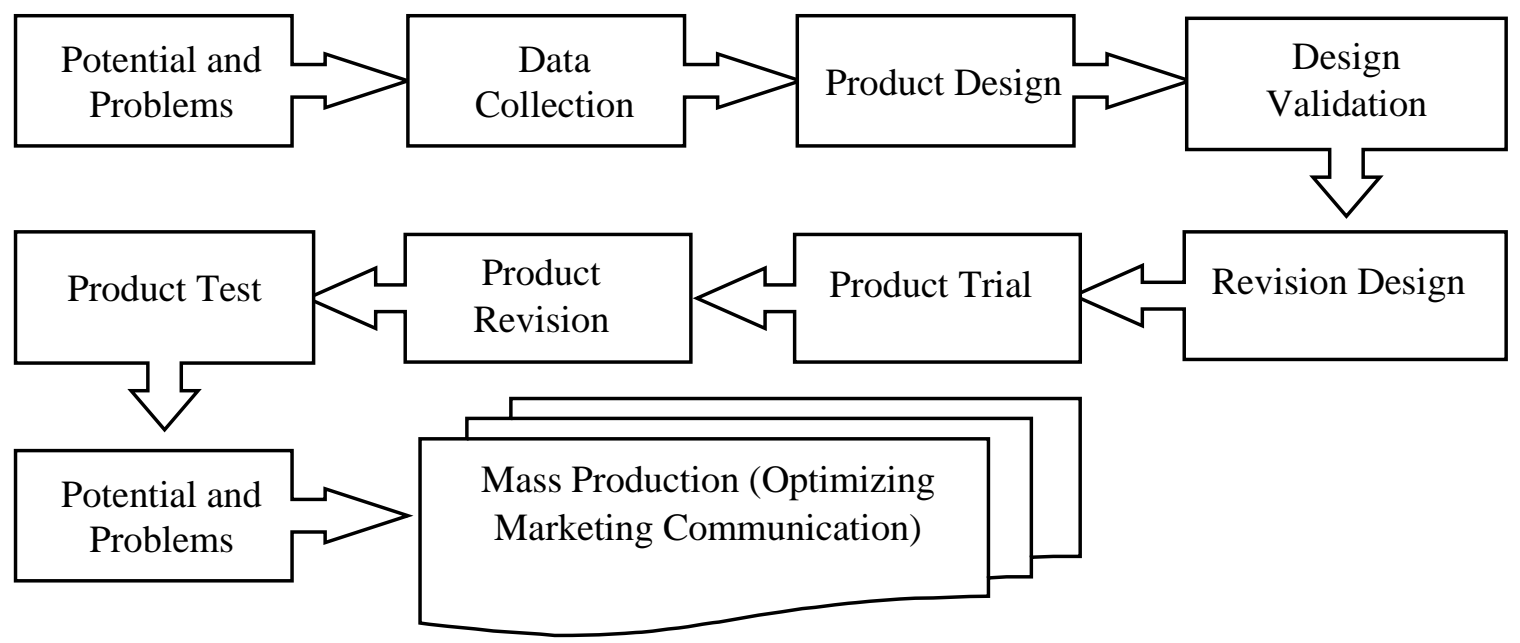

\section{Canvas Business Model}

In 2010, Osterwalder and Pigneur launched a book entitled "Business Model Generation," which contains how to design business models quickly and efficiently, even for the people who are not business school graduates. Canvas Business Model is a tool for creating and developing a business model with the "nine key elements of a business in one page" format that allows businesses to quickly and repeatedly create their business model plans. The one-page form will enable us to see the relationship between elements and evaluate and rectify the mislinkedor have not been thought of. Those nine key elements are:

1. Customer Segments: Blocks explaining the concept of customer segments.

2. Value Propositions: Blocks describing the value offered by a product or service.

3. Customer Relationships: Blocks explaining how the company deals with customers.

4. Channels: Blocks describing the media used by the company is interacting with customers.

5. Key Activities: Blocks describing the main activities of a business.

6. Key Partners: Blocks explaining the system and motivation of cooperation.

7. Essential Resources:Blocks describing the primary resources of a business.

8. Cost Structures: Blocks describing the corporate financing structure.

9. Revenue Streams: Blocks explaining the types of income streams, pricing concepts, and payment methods.

The Canvas Business Model is different from a formal and complex business plan.A business model is more about designing how we formulate,creating products/services that can convey our value to the right customer,deliver it, and finance and gain profit from the activity before launching the business.In this research on the tourism packagesinnovation in Bilebante Green and Sesaot Green Tourism Village, the Canvas Business Model Canvas was 
used to overview the tour packageproduct design to generate products and services that can bring multiple benefits for DWH managers. The BMC description is as follows:

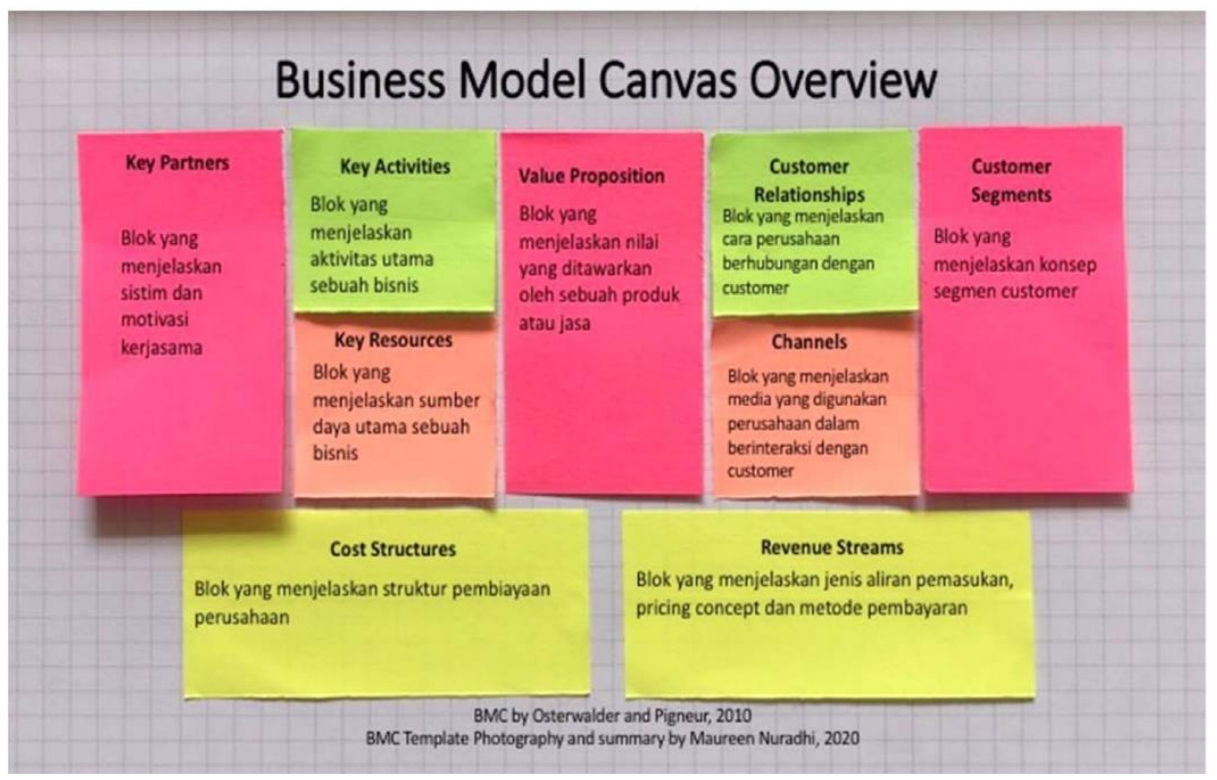

The advantages of the BMC concept created by Osterwalder are:

1. It has a very communicative form and is easy to use, that is: "9 key elements of a business in one canvas."

2. It allows us to make creations and corrections quickly and repeatedly.

3. It helps us see the relationship between key elements.

4. It assists us in evaluating and rectifying what is wrong,what is related, or not associated with it even though it needs to be linked.

From the 9 BMC blocks, each block has several alternative models so that if the businesses mix and match between theseblocks, they can produce millions of alternative business models. This canvas business model is used to see how the product designs made by two villages create innovation from the planned tour package products.

This research is qualitative. Qualitative research is a study based on positivism. It was used to examine the condition of natural objects where the researcher is the key instrument, data collection techniques were carried out by triangulation (combined), data analysis is inductive/qualitative, and the research results emphasize meaning instead of generalization. (Sugiyono, 2012: 9). When analyzing qualitative data, it usually takes the description first, so in analyzing the data, the author uses a qualitative descriptive method. This method is used to describe the Application of the Canvas Business Model in tourism package innovation. During the interview, the researcher must analyze the respondent's answers. If the respondent's response is not satisfactory, the researcher will continue the question again until a particular stage is obtained the credible data.

The qualitative data analysiswas carried out interactively and took place continuously until complete so that the data was saturated. The steps in data analysis are data reduction, data display, and concluding/verification.Furthermore, according to Janice McDrury (in Moleong, 2013: 248), the stages of qualitative data analysis are as follows: 1) Reading/studying the data, marking keywords and ideas in the data; 2) Studying the keywords, trying to find themes coming from the word; 3) Writing down the "model" found; 4) Coding of what has been done. According to Seiddel (in Moleong, 2013: 248), the qualitative data analysis process follows 1). Taking notes fromthe field, they are coded so that the data source can still be traced. 2). Collecting, sorting, classifying, synthesizing, summarizing, and indexing them. 3). Thinking, by making the data categories have the meaning, looking for and finding patterns and relationships, and causing general findings.

Referring to the steps mentioned above, the actions taken by researchers in data analysis are as follows:

1) Making notes in the field (data collection)

2) Making research notes (taking notes or writing and should not be delayed)

3) Editing data

4) Grouping similar data

5) Searching and finding patterns

6) Performing data interpretation

7) Drawing conclusions 
International Journal of Social Science (IJSS)

Vol.1 Issue.4 December 2021, pp: 437-448

ISSN: 2798-3463 (Printed) | 2798-4079 (Online)

DOI: https://doi.org/10.53625/ijss.v1i4.735

\section{RESULTS AND DISCUSSION}

In general, these two villages have developed their villages into tourist villages, and theycan last more than five years. In developing tourism villages and developing better tour packages, they continue to improve standards and use new tools. The innovation process carried out on the tour package products should be truly valid, desirability, feasibility, and viability. It has the competence to be marketed, and indeed it will bring more guests than before the innovation was carried out.The innovation process carried out will refer to the process adjusted to Law No. 19 of 2002. Innovation is a research, development, and or engineering activity carried out for developing the practical application of new scientific values and contexts or new ways to implement the existing science and technology into products or production processes. Then it is not yet called innovative. Moreover, following the innovation process starting from the potential and problem discovery process, data collection, product design, design validation, design revision, product testing, product revision, product trial after modification, potential and problems, and finally, the production of the issues (marketing for service products) tour packages. With the following process:

\section{Potential and Problems}

The process for developing a tour package departs from the potential and problems. Potential is anything that, when utilized, will produce value. DWH Bilebante's potential, as mentioned in the research results above, is that two ethnic residentslive in the village, the Sasak ethnic and the Balinese ethnicity. The existence of the Datu Rangge Tapontomb, fishing ponds and sloping and vast expanses of rice fields, Nyanggetwells, ancient durian trees, herbal gardens, herbal therapists and herbal medicine production, and also friendly people and MSMEs which have been a place forstudent's training and practice for a long time.DWH Sesaot has some natural potential, such as forests, waterfalls, Purekmas as a public bathing place that local people have long visited.There are MSMEs, cultural customs, and it is also inhabited by two ethnic groups, Sasak and Balinese.

While the problem is that the difference betweenwhat was occurred and what was expected, this research was able to find out the issues faced by the two DWHs so that it triggers many ideas to make tour packages.As for the problems faced by DWH Bilebante, that is, the damaged roads and rice fields due to excavations carried out by the community, many community members were trying their luck abroad due to lack of job opportunities. Subsequently, DWH Sesaot has problems related to illegal logging carried out by the community, the unmanaged river, which is a bathing place for the community. The issues werenot only come from the Sesaot area but also Central Lombok or East Lombok.Additionally, the lack of employment opportunities and early marriages are the other problems.

This study found that the two villages already knew and understood the potential and problems they had and faced. All kinds of possibilities and issues have been thought out and discussed by the tourism village manager with community leaders and village tourism

These two villages have explored their potential, which can be used as a tour package offered to the target market. And it seems that the series of activities indiscussing and analyzing DWH's potential and the surrounding environment can be used as inspiration for making tour packages.If the potential exploration is done thoughtfully, it will help DWH identify problems with business opportunities. Therefore, many entrepreneurs have stated that in every situation, there is an opportunity hidden. (Ciputra, 147).

Tim Brown mentions that the problems experienced by consumers determine the level of desirability for a product or service. When a product or service can solve the problems faced by many people, and there is no similar solution, then the desire or market interest in the product or service is high. This is one of the requirements to alter the product or service into a business. Therefore, DWH needs to map all consumer problems related to DWH. Thus, DWH will determine tour package products that are attractive, feasible, and stand out and will undoubtedly benefit DWH.

\section{Data Collecting}

After the potential and problems can be shown factually and up to date, it is necessary to collect various information that can be used as material for planning tour package products expected to overcome the problems faced by the villages. As the informant in this study, the tourism village manager has collected data about the towns' potential and issues. Still, such dataof possibilities and problems faced by valuable consumers have not been carried out in detail and planned, only in the form of PPT, which was used as material for presentations. When participating in training or competitions. Whereas the results of accurate problem identification will produce a useful PBB (Business Opportunity Problem) (Ciputra: 148) as a tool for:

1. Determining the purpose of making business (tour package products)

2. Triggering solutions as the basis for the value proposition

3 . Working guidance when planning a business model from that value

4. Validation tools from product/service prototypes and business models 
Contents of campaigns in marketing products/services. The tour package products made by DWH are expected to generate economic value that can improve the DWH's welfare. Each packaging product has a business vision, has a value proposition, target market, media used for promotion, financing, andlegitimate sources of income. Potentials and problems that have been explored and analyzed in the business environment will be used as PBB by following these steps: (Ciputra: 149).

Make a preliminary list of problems from each point of the business environment analysis (potential)

Find out if the problem already has a solution proposed by

someone else, what are the advantages and disadvantages of the solution

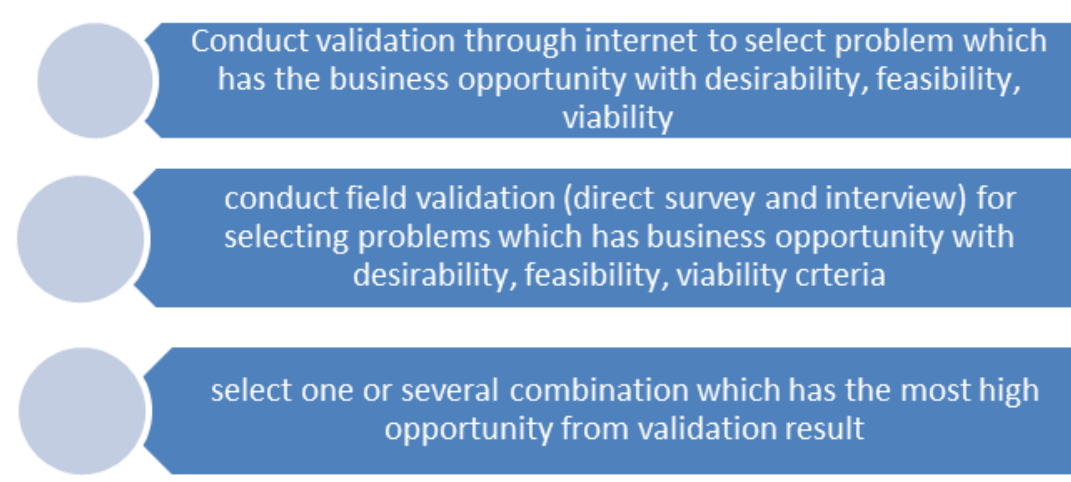

This study has not found any written and detailed identification. Complicated problems identification will provide extensive information. There will be many choices from DWH managers to make innovation in formulating tour packages and indeedcreating desirability, feasibility, and viability tour packaging.

\section{Product Design}

The product design applied to get the tour package product desired by the customer has feasibility and guarantees the product's viability. It is necessary to design the product in a business plan, a business model canvas. Canvas Business Model is a tool for creating and developing a business model with the "nine key elements of a business in one page" format that allows businesses to quickly and repeatedly create their business model plans. The one-page form will enable us to see the relationship between elements, evaluate and correct the wrong links or missed and unthinkable. The nine main components are:

1) Customer Segments: Blocks explaining the concept of customer segments.

2) Value Propositions: Blocks describing the value offered by a product or service.

3) Customer Relationships: Blocks explaining how the company deals with customers.

4) Channels: Blocks describing the media used by the company is interacting with customers.

5) Key Activities: Blocks describing the main activities of a business.

6) Key Partners: Blocks explaining the system and motivation of cooperation.

7) Essential Resources:Blocks describing the primary resources of a business.

8) Cost Structures: Blocks describing the corporate financing structure.

9) Revenue Streams: Blocks explaining the types of income streams, pricing concepts, and payment methods.

The Canvas Business Model is different from a formal and complex business plan.A business model is more about designing how we formulate,creating products/services that can convey our value to the right customer,deliver it, and finance and gain profit from the activity before launching our business.

The advantages of the BMC concept created by Osterwalder are:

1) It has a very communicative form and is easy to use, that is: "9 key elements of a business in one canvas."

2) It allows us to make creations and corrections quickly and repeatedly.

3) It helps us see the relationship between key elements.

4) It assists us in evaluating and rectifying what is wrong, related, or not related to it even though it needs to be linked.

The results of observations, interviews, and documentation from this study have not found a natural product design/business plan of a tourism product made by the two DWHs. Moreover, they have not made business 
International Journal of Social Science (IJSS)

Vol.1 Issue.4 December 2021, pp: 437-448

ISSN: 2798-3463 (Printed) | 2798-4079 (Online)

DOI: https://doi.org/10.53625/ijss.v1i4.735

modelslike the Canvas Business Model, but these two DWH managers were once heard of BMC, both in terms of its form and benefits.

However, from the interview results conducted in this study, the nine elements that must exist in the business model canvas already exist. They have thought about it or discussed it with managers, the community, experts, or the village government. We describe the business model that the two DWHs should make are as follows:

Figure 4.2. BMC Pokdarwis DWH Bilebante

\begin{tabular}{|c|c|c|c|c|}
\hline $\begin{array}{l}\text { KEYPARTNERSHI } \\
\text { PS: partnership: } \\
\text { strategic alliance } \\
\text { model } \\
\text { - Local } \\
\text { government/village Civil } \\
\text { Officers } \\
\text { - Bumdes } \\
\text { - Village } \\
\text { Community Youth } \\
\text { - Farmers } \\
\text { - MSME actors } \\
\text { - Tour Guide } \\
\text { - Travel Agent }\end{array}$ & $\begin{array}{l}\text { herbs } \\
\text { Presenting quality MSME } \\
\text { products at affordable prices } \\
\text { - Conducting touring } \\
\text { throughout the tourist area to } \\
\text { enjoy nature comfortably by } \\
\text { bicycle } \\
\text { - Maintain a sustainable, clean, } \\
\text { and comfortable village } \\
\text { natural atmosphere } \\
\text { - Implementing health protocol } \\
\text { conforming to CHSE (Clean, } \\
\text { Health, Safety, Environment } \\
\text { Sustainability) } \\
\text { KEYRESOUR } \\
\text { CES PSOSical: } \\
\text { Physical } \\
\text { - Farmers' active rice } \\
\text { fields } \\
\text { Farmers' farms Community- } \\
\text { owned gardens } \\
\text { Environmental } \\
\text { sustainability } \\
\text { - Maintain the area } \\
\text { cleanliness }\end{array}$ & \begin{tabular}{|l} 
VALUE \\
PROPOSITIO \\
NS \\
- Green, \\
beautiful, and \\
natural spots \\
- Rice fields \\
- Herbal garden, \\
herbal \\
medicine, and \\
therapist \\
- MSME's \\
flagship \\
product \\
Local food and \\
drinks served \\
next to rice \\
fields and \\
herbal gardens \\
- Education \& \\
fungame \\
Ancient durian \\
Grand Canyon \\
Lombok \\
(Crook Round) \\
Homestay \\
- Nyangget well \\
\end{tabular} & $\begin{array}{l}\text { ELS } \\
\text { ity } \\
\text { hotion } \\
\text { ion } \\
\text { guides } \\
\text { travel } \\
\text { ation } \\
\text { schools } \\
\text { rnment } \\
\text { gchures } \\
\text { rs }\end{array}$ & $\begin{array}{l}\text { CUSTOME } \\
\text { R } \\
\text { SEGMENT } \\
\text { S } \\
\text { - Market } \\
\text { Model: } \\
\text { Mass } \\
\text { - Foreign } \\
\text { tourists } \\
\text { - Family } \\
\text { Traveler, } \\
\text { - Early } \\
\text { Childhood } \\
\text { Education, } \\
\text { Elementar } \\
\text { y, Middle } \\
\text { School, } \\
\text { High } \\
\text { School \& } \\
\text { College, } \\
\text { Millennial } \\
\text { Travelers } \\
\text { - Herbal \& } \\
\text { Healthy } \\
\text { connoisseu } \\
\text { rs }\end{array}$ \\
\hline \multicolumn{2}{|c|}{$\begin{array}{l}\text { COST STRUCTURE } \\
\text { Model Cost: Value Driven } \\
\text { Fixed Cost } \\
\text { Pay employee salaries } \\
\text { Operational costs: Electricity and water } \\
\text { Variable Costs: } \\
\text { Promotion fee }\end{array}$} & \multicolumn{3}{|c|}{$\begin{array}{l}\text { REVENUE STREAMS } \\
\text { Model Stream: Usage Fee, Rental Fee,Asset sale } \\
\text { - Package Seller } \\
\text { - Entrance Ticket Sales } \\
\text { - Photo objects rentals } \\
\text { - Food and beverage products Sales } \\
\text { - Souvenir sales } \\
\text { - Spot ads/sponsors }\end{array}$} \\
\hline
\end{tabular}

Figure 4.3. BMC Pokdarwis DWH Season 


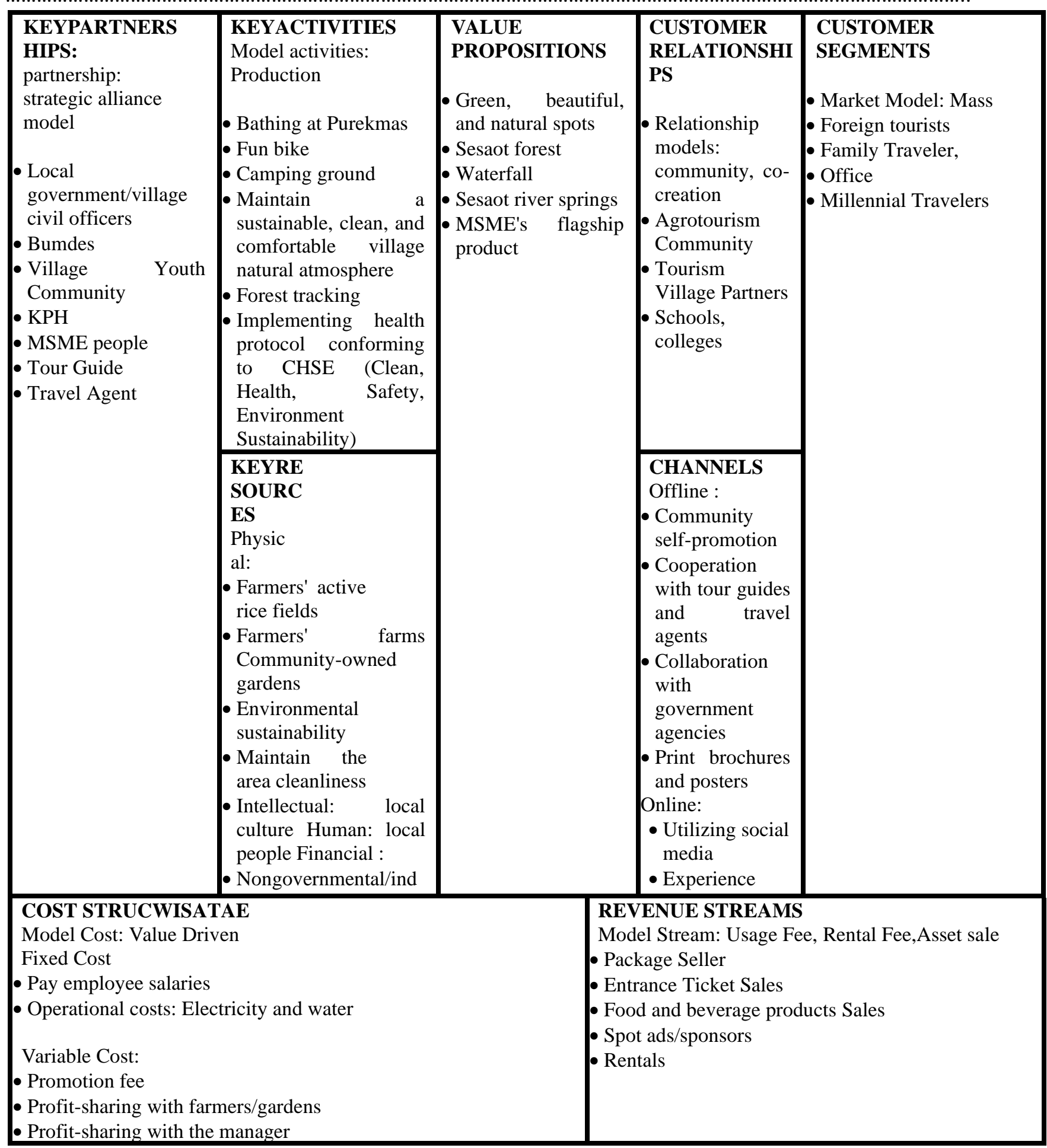

\section{Design Validation}

Design validation is an activity to assess whether the tour package product design was designed aligned to the canvas business model. And rationally, this validation will only be much effective than the designed design.It is said rationally because the validation is still an assessment based on rational thinking, not facts on the field.

Validation is a testing process before carrying out a public release or mass production of a business idea for a previously thought-out tour package product. Validation is more like a research and development process that a business uses to test the product ideas before release.Validation can be researched with survey coverage, interviews, 
International Journal of Social Science (IJSS)

Vol.1 Issue.4 December 2021, pp: 437-448

ISSN: 2798-3463 (Printed) | 2798-4079 (Online)

DOI: https://doi.org/10.53625/ijss.v1i4.735

online research, literacy studies,etc., to get the best results. Lean Market Validation is the process of determining whether a product is attractive or not to a particular target market.

An idea without valid data is just an assumption. This sentence is a crucial keyword for why a business validation needs to be done. Business people will feel that consumers need their business because they know about the industry, but after it is released, it does not mean many consumers also want to buy the product. It is because ordinarybusiness people were not validated whether consumers need it, so validation needs to be done to get actual data about consumer requirements for the idea.

The tour package productsvalidation made by the two villages has brought several experienced travel practitioners to assess the new products designed. The validation has not been thorough that it has not been able to produce a tour package product that is very attractive and deserves to be accepted by the target market.

The interview results with the two DWHs have not shown any validation to the tour business design they made, even though they already understand the benefits or functions of a tour business design validation.

\section{Design Revision}

After the product design is validated through discussions or FGDs with tourism experts or practitioners, the tour package products' weaknesses will be identified. These weaknesses are then minimized by improving the design.

It isessentialto know and understand the weaknesses of a tourism product design after being assessed by tourism practitioners. It will make the DWH manager more professional to present a tourism product. It will surely minimize all the weaknesses that eventually cause this product to be rejected by the potential customer. However, this research results have not shown any validation or design to the tour package product.

\section{Product trial}

Tour package products can be tested immediately after being validated and revised. The initial trial is carried out by simulating the service in the tour package products that have been made. After being manufactured, it can be tested on a limited group. The test was aimed to obtain information on whether the tour packages made were effective or not.

The research results conducted on the two DWHs indicate that trials areshown on the tour package products they made. However, there has been no design, design validation, or business design revision to the tour package products they made. This means that the two DWHs jump from discovering the problems and the potential to test the products they make directly in their innovation process. With this unprofessional leap, the research found many weaknesses in the two villages' tour package product business launched to the market.

\section{Product revision}

If the tour package product testing has been effective according to the plan, the tour package can be sold to a broader target market. Subsequently, if the testing of this tour package product has not been effective and valid, then the tour package product needs to be revised. After being repaired, it was conducted to make a trial to a broader target market.After the tour package product is sold for one year, it needs to be rechecked, and maybe there are still weaknesses. The product needs to be repaired immediately and then mass-produced or sold to the public market.

This study results indicate that the two DWHs have revised the tour package products trial that they marketed both in terms of presentation services or menu attractions served to their customers. DWH Bilebante changed the bicycle route package, which was initially short, only taking one hour, but after improvements were made, the bicycle route needed 3 hours.Moreover, improvement in the food menu, precisely in sambalby making it less spicy than before.

Likewise, DWH Sesaot has revised its tour package products, such as the Sesaot forest tracking tour package to the Semporonan waterfall and back exploring the rice fields. The fixed attraction is to dine besidethe rice fields, which previously wereeating in the middle of the forest. However, this package product has not been marketed due to natural disasters. That is, the earthquake and corona outbreak hit Lombok.Eventually, this package cannot be sold.

\section{Product trial of Tour Package}

After testing, the tour package products arebooming, and there may be revisions that are not too important. The tour package products can be marketed widely, nationally, domestically, or internationally.

The study results explained that the two DWHs conducted no tour package trials because they directly marketed the tour package products to the target market. Here, they run the test by the simulation to prospective customers such as PKK groups, government agencies or Pokdarwis members, or tourism practitioners, such as tour guides, tour leaders, journalists, etc.However, this study results indicate that Pokdarwis is testing its products to the target market directly.

\section{Potential and problems}

After the trial, of course, the tour package products'potential and problems that have been tested will be found.However, there must be shortcomings and weaknesses tothe potential shown. Thus, this tour package product 
must be evaluated so that the existing weaknesses can be identified to be used for improvement and create a new tour package product.

Thisstudy results indicate that DWH found new potentials and new problems from the previous product trials. Of course, these potentials and problems will still be identified to support the improvement of tourism products for a DWH.

\section{Mass production (marketing)}

Suppose the tour package product has been declared desirable and feasible in several tests. In that case, the product can be widely marketed to the target market corresponding to the established marketing plan. Mass production of service products does not mean making as many tour package products as possible. Still, it will be marketed to the target market as often as possible and keep it highly rated in digital marketing.

Marketing a tour package product will make many people know the outcome, thereby selling the product. Tour package products sold were worked as planned and even surpassed the expectation. It means that the product will be the flagship of DWH. This superior product will be able to bring benefits to Village tourism.

This study results show that tour package products are sold massively by the two DWHs, such as DWH Bilebante still marketing bicycle package products, meal packages at the edge of the rice fields, and educational packages.Meanwhile, DWH Sesaot still exists to sellPurekmas and re-market the Sesaot forest tracking tour package.

Research in these two DWHs shows that there is an innovation in every plan they do. Specifically, DWH Bilebante shows the results in every innovation they made, such as providing aid in billion Rupiah to build the Thematic Market or Wellness Market.And when this research was conducted, the product had been tested for educational packages and fungames for elementary/Madrasa children. Still,it was not continued, or it did not followthe correct innovation process.

Indeed, innovation must be carried out. Innovation is an improvement to all aspects of product quality and must be achieved by every business organization if it wants its customers not to switch to competitors. In today's alldigital era, competitors quickly appear, either with similar products or substitute products. Therefore, every business manager must plan continuous and careful innovationto survive in the business. For business people, innovation is no longer an option at a crossroads. Innovation is about seeing the opportunities - the courage to undergo an uncertainty to create a masterpiece. For businesses, innovation is not just catching profit, nor just for a catch up the pace. Innovation means always being relevant in all ages (Febransyah, 2016. 11). Do it fast, do it right, do it cheaply, choose two of the three (Leslie Pockell \& Adrienne Avila: 40) to face uncertainty due to various kinds of disasters or increasingly crazier competition.

The tourist villages management cannot be separated from the entrepreneurial mentality that is never separated from innovation and creation to create new tour package products and provide maximum satisfaction to guests visiting the destinations. The tour package product is part of the service or attraction that must be served by a tourist destination, including a tourist village. Regarding the notion, a tour package or interest that is part of the service must be innovative. Furthermore, tourism innovation is expected to improve the destinationimage and increase tourist satisfaction in the service (Gupta, Malhotra, Czinkota, \& Foroudi, 2016; Hertog, 2000).

Mansori et al. (2015) mention product innovation involve introducing a new brand or significantly improving a product or service to the market. Therefore, it represents the improvement made to the goods or services which can be commercialized. Product innovation has preceded performance improvements in the marketplace (Artz, Norman, Hatfield, \& Cardinal, 2010; Cho \& Pucik, 2005; Koelinger, 2008)Mansori et al. (, 2015). It emphasizes sustainability, clients, technology orientation, innovation, risk management, structured collaboration, and a training workforce that essentially enables travel practitioners to preserve sustainable company operations (Assaker, Vinzi, \& O'Connor, 2011; Dwyer \& Edwards, 2009). The offer and markets need to be unique enough to achieve product differentiation, and the product developmentrelevance has gained widespread recognition across businesses (Klaus, 2006; Kuncoro \& Suriani, 2018).

To attract customers, tourism destination operators must plan and implement innovative approaches (Santos, 2014). They're starting to offer unavailable experiences, including creative services and products that force travelers to innovate (together) to create experiences. Being innovative, tourist destinations must be accessible to everyone, ease interaction and integration, and provide high-quality services.In particular, tourism destination products are 'interdependent,'a mixture of tangible and intangible: physical products, people, packages, and programs (Morrison, 2013: 156). It combines diverse, often eclectic, attractions, activities and activities, sights, accommodations, amenities, climate, and people that can be packaged in a unique way to attract tourism choices.

Tour packages can attract tourists because they make traveling more accessible and convenient, an essential element of a destination product. They also offer a reasonable and effective way for travelers to travel safely, visit many places in a short period, and receive reliable and convenient service.Package tours generally incorporate 
International Journal of Social Science (IJSS)

Vol.1 Issue.4 December 2021, pp: 437-448

ISSN: 2798-3463 (Printed) | 2798-4079 (Online)

DOI: https://doi.org/10.53625/ijss.v1i4.735

schedules developed by travel agents; agents who work for tour operators and other travel planners helpestablish, time, and sell their company's travel and tourism services.

The circulation of an ecosystem in tourism has one central aspect: tour packages or tourist attractions. The basic concept of a tourist destination or Tourism Village used as a tourist destination target is where the location must be seen. There are activities carried out and something to be purchased. The classic concept of "something to see, buy and do" is a basis that Tourism Villages must own.Of course, many things were created in these essential components, always up to date in the era. Tour packages or tourist attractions can be packaged in cultural nuances, nature, artificial parks, history, culture, or something modern.

Tourism Village in creating a tour package or tourist attraction must make attractive and worthy. Itis used as a reference for tourist destinations; innovation is needed to assemble and change a place, culture, customs, and various existing community activities into tour packages or attractions that can bring visitors.DWH Bilebante and DWH Sesaot are fortunate villages blessed with beautiful nature and culture, extraordinary local culinary richness, and friendly and tolerant people. These aspects make these two villages have huge tourism potential. But unfortunately, not all potential is managed optimally.Several essential stakeholders contributing to tourism development in the industryare the government, entrepreneurs, and the community, which are crucial pillars in developing tourism. In this case, community participation is needed in tourism development, primarily based on nature and culture. Many forms of community creativity are currently carried out in the two villages, mainly to utilize the existing nature.

In the context of developing the village as a new tourist attraction, a joint commitment is needed by all parties, especially from managers, village officials, and the community. Stakeholders must agree to have the same concept and objective in the development process. The idea of developing a Green Tourism Village in Bilebante and Sesaot was inspired by the surrounding community's enormous natural and cultural potential and the agricultural, forest, and MSME products they have.For the sake of perfecting the tour package designed or for the DWH management, the manager must be able to focus on preparing each tour package they madetoestablish various kinds of high demand, feasible and sustainabletour packages.

In general, these two DWHs can be categorized as innovative in which previously they did not have a tourist village. DWH Bilebante is a village with extensive sand excavations, even though the land taken from the sand is very fertile agricultural land or first-class agricultural land.It is possible that if this village is not developed into a tourist village, all the rice fields in this village will become a sand dug area. Still, thanks to the community members hard work and village officials who love environmental sustainability, and this village is made into a tourist village. Thus, entrepreneurs who want to excavate sand in the middle of fertile rice fields have no chance to run their businesses.

Meanwhile, DWH Sesaot also experienced similar problems. The fertile and dense forest of Sesaot was used as illegal logging land by people who wanted to plant this forest into plantations by planting consumable fruit trees to be sold. Planting these fruitful trees is very profitable, but basically, it will damage the forest ecosystem as a rainwater catchment area. If heavy rains occur, landslides will happen because no trees can hold the soil, and water seeps into the ground.

The packages made can be innovative, but if one followsthe Law No. 19 of 2002, innovation is a research, development, and or engineering activity carried out for developing the practical application of new scientific values and contexts or new ways to apply the existing science and technology into products or production processes. Then it is not yet called innovative.Moreover, following the innovation process starting from the potential and problem discovery process, data collection, product design (designing with a canvas business model), design validation, design revisions, product trials, product revisions, product trials after corrections, potentials and problems, and finally the production of the issues. (service product marketing) tour packages.

\section{REFERENCES}

[1] Ade Febransyah 2016. 50/50 Belajar Inovasi untuk menang. Gramedia

[2] Akroush, M. N., Jraisat, L. E., Kurdieh, D. J., AL-Faouri, R. N., \& Qatu, L. T. (2016). Tourism service quality and destination loyalty-the mediating role of destination image from international tourists' perspectives. Tourism Review.

[3] Al-khowarizmi Ryadu et al., tentang Kemampuan Inovasi Memediasi Pengaruh Orientasi Kewirausahaan Terhadap Kinerja Produk IMK Sektor Industri Makanan di Kota Denpasar tahun 2016.

[4] Belch, George E, Belch Michael A. Advertising and Promotion: An Integrated Marketing Communication Perspective. Edisi ke Delapan, McGraw-Hill, New York.

[5] Bungi, Burhan. 2015. Komunikasi Pariwisata : Pemasaran dan Brand Destinasi. Jakarta : Kecana.

[6] Candra Nugraha, Widya, 2019; PENYUSUNAN PAKET WISATA KELUARGA BERDASARKAN KARAKTERISTIK OBYEK WISATA KABUPATEN REMBANG JAWA TENGAH. UNiversitas Muhammadiyah Surakarta. 
[7] Cheng, B. L., Nikhashemi, S., \& Dent, M. M. (2020). The chain effects of service innovation components on the building blocks of tourism destination loyalty: the moderating role of religiosity. Journal of Islamic Marketing

[8] Daryanto Aris Dwi Cahyono: Kewirausahaan (Penanaman Jiwa Kewirausahaan) Gava Media: 2013)

[9] Duncan, Tom. 2002. IMC Using Advertising \& Promotion to Build Brands. International Edition. Kotler, Philip dan Amstrong, Gary. 1992. Dasar Pemasaran. Fifth Edition. Jakarta: Intermedia.

[10] Fitrianna, Hafizh, 2018; PELUANG, TANTANGAN DAN STRATEGI PENGEMBANGAN USAHA PAKET WISATA 'ROMANTIC TOUR' DARI MPUKIYUPS TOUR DI YOGYAKARTA. UII

[11] Fransiska dkk, 2020; PERENCANAAN PAKET WISATA ROHANI DI DAYA TARIK WISATA SA'PAK BAYOBAYO KABUPATEN TANA TORAJA, Jurnal HomeEc (ISSN: 1907-508) VOLUME 15, No. 2, November 2020.

[12] Hall, M. C., \& Williams, A. (2019). Tourism and innovation: Routledge.

[13] Ristawati, H., Saufi, A., \& Rinuastuti, B. H. (2019). Effect of Customer Experience and Innovative Value on Halal Destination Image and Satisfaction of Domestic Tourists in Lombok Island. Global Journal of Management And Business Research.

[14] Sugiyono, Metode Penelitian Pendidikan;Pendekatan Kuantitatif, Kualitatif dan R\&D, (Bandung: Alfabeta, 2008)

[15] Terence Shimp A. 2003. Periklanan dan Promosi. Jakarta: Erlangga.

[16] W. Faché (2010),"Capabilities for managing service innovation: towards a conceptual framework," Journal of Service Management, Vol. 21 Iss 4 pp. 490-514 http://dx.doi.org/10.1108/09564231011066123 